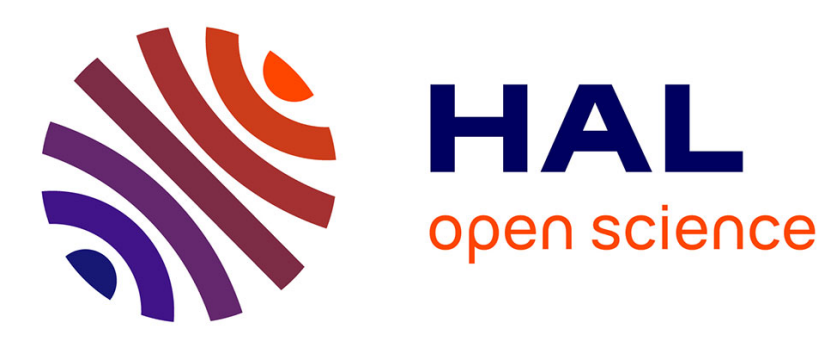

\title{
Monetary Policy and Corporate Investment in France
} Jean-Bernard Chatelain, Andre Tiomo

\section{To cite this version:}

Jean-Bernard Chatelain, Andre Tiomo. Monetary Policy and Corporate Investment in France. Angeloni Kashyap Mojon. Monetary Policy Transmission in the Euro Area, Cambridge University Press, pp.187-197, 2003. halshs-00112523v2

\section{HAL Id: halshs-00112523 \\ https://shs.hal.science/halshs-00112523v2}

Submitted on 15 Nov 2009

HAL is a multi-disciplinary open access archive for the deposit and dissemination of scientific research documents, whether they are published or not. The documents may come from teaching and research institutions in France or abroad, or from public or private research centers.
L'archive ouverte pluridisciplinaire HAL, est destinée au dépôt et à la diffusion de documents scientifiques de niveau recherche, publiés ou non, émanant des établissements d'enseignement et de recherche français ou étrangers, des laboratoires publics ou privés. 


\title{
MONETARY POLICY AND CORPORATE INVESTMENT IN FRANCE ${ }^{1}$
}

\author{
Jean-Bernard Chatelain ${ }^{2}$ and André Tiomo ${ }^{3}$
}

2003

\begin{abstract}
:
Using a large panel of 6946 French manufacturing firms, this paper investigates the effect of sales, of the cost of capital and of liquidity constraint variables (cash flow or cash stock) on the stock of capital from 1990 to 1999. The user cost elasticity is at the most 0.26 in absolute terms for all the firms of the sample. Three groups of firms representing around 20 per cent of the sample (firms facing a high risk of bankruptcy, firms belonging to the capital goods sector, firms making extensive use of trade credit) are more sensitive to cash flow. Risky firms are less sensitive to sales, when cash stock replaces cash flow. Simulations following shocks of interest rate (related to monetary policy shocks), provides short run contemporaneous elasticities of investment with respect to interest rate through the user cost and through debt repayments taken into account in cash flow.
\end{abstract}

Keywords: Investment, User Cost of Capital, Liquidity Constraints, Monetary Policy Shocks.

JEL classification numbers: D92.

\section{Résumé:}

A l'aide d'un échantillon de 6946 bilans annuels d'entreprises industrielles françaises, cet article évalue les effets de ventes, du coût moyen pondéré du capital et de variables pouvant signaler des contraintes de liquidités (autofinancement ou trésorerie) sur l'investissement corporel de 1990 to 1999. L'élasticité estimée du stock de capital au coût moyen pondéré du capital est au plus égale à 0,26 en valeur absolue pour l'ensemble de l'échantillon. Pour ce qui est du canal du crédit, trois groupes d'entreprises représentant environ $20 \%$ de l'échantillon (entreprises présentant un score indiquant un risque de faillite élevé, entreprises appartenant au secteur des biens d'investissement, entreprises ayant un recours important aux dettes fournisseurs) ont des investissements plus sensibles à l'autofinancement. Lorsque la trésorerie remplace l'autofinancement, les entreprises risquées ont des investissements moins sensibles aux ventes. Pour différents groupes d'entreprises, les simulations des effets dynamiques d'un choc de taux d'intérêt (éventuellement associé à un choc de politique monétaire) fournissent les élasticités de court terme du capital au taux d'intérêt via le coût du capital ou via les charges d'intérêts à même de modifier l'autofinancement.

Mots clés : Investissement, coût du capital, contraintes financières, choc de politique monétaire.

\footnotetext{
${ }^{1}$ We would like to thank Steve Bond, Paul Butzen and Philip Vermeulen for their contributions to the previous versions of this paper, as well as Ignazio Angeloni, Andrea Generale, Ignacio Hernando, Ulf von Kalckreuth, Anil Kashyap, Benoît Mojon, Daniele Terlizzese and all other participants in the ESCB monetary transmission network and in the related ECB conference for their helpful comments. The usual disclaimer applies. "Monetary Policy Transmission in the Euro Area", (2003), Angeloni I., Kashyap A. and Mojon B., editors, Cambridge University Press, pp.187-197.

${ }^{2}$ Laboratoire d'Economie d'Orléans (LEO), University of Orléans, Rue de Blois, BP 6739, Orléans Cedex 2. E-mail : jean-bernard.chatelain@univ-paris1.fr.

${ }^{3}$ Banque de France.
} 


\section{Introduction}

In this paper, we complete the presentation and discussion of the estimated effects of monetary policy on French corporate investment reported in Chatelain et al. (2003) and in Chatelain and Tiomo (2002). We focus on the measurement of the impact of the cost of capital channel and the credit channel of monetary policy on investment.

On the one hand, the available macroeconomic level evidence shows that the cost of capital channel of monetary policy has no or little effect on corporate investment in France. For instance, neither Amadeus (INSEE), nor Mosaïque (OFCE) nor the model developed by the Banque de France, three French forecasting models developed in the 1990s, include the cost of capital effect on investment. INSEE's Metric model adds a relative factor cost whose parameter is small and not significant (see Assouline et al. [1998]). Herbet [2001] published a recent estimation of macroeconomic investment and recognised its failure to incorporate interest rate or user cost effects.

On the other hand, some of the studies that have used sectoral-level data find large and significant investment elasticity to the user cost of capital. Using the BACH European database "aggregated by size and sector" based on Banque de France sample data for French data, Mojon Smets and Vermeulen (2001) obtained an elasticity for the user cost of -0.75 . Duhautois (2001), who used data aggregated by sector and size from 1985 to 1996 on the basis of the INSEE BIC-BRN, found a real interest rate elasticity of -0.38 for the period 1985-1990 and of -0.27 for the period 1991-6. However, Beaudu and Heckel (2001), who also used BACH, found a zero elasticity.

Finally, Crépon and Gianella (2001), who used a sample of individual firm accounts (INSEE BIC database), obtained an user cost elasticity (UCE) of -0.63 for industry and of -0.35 for services for the two years 1990 and 1995.

These studies show that we obtain a high user cost elasticity if (1) the sample period is short and/or (2) the cash flow or the growth of sales is omitted from the regression and/or (3) within estimates are used instead of dynamic panel data estimates, as in the generalised method of moments (Arrelano and Bond (1991)) and/or (4) when defining the user cost, the marginal cost of debt is approximated by an average cost of debt at the firm level instead of an average interest rate at the national level for all firms.

Turning to the credit channel, several studies have indirectly addressed its relevance in France by testing the existence of liquidity constraints on individual firms' investment. The main result is that financial variables (notably cash flow) affect the investment of groups of firms that are likely to be financially constrained (see Chatelain (2002)). Several studies have tested excess sensitivity of investment to liquidity variables, 
such as cash flow, the stock of cash, leverage and the coverage ratio (see the references in Bond et al. (1997) and Hall, Mairesse, Mulkay (1999 and 2001)).

Crépon and Rosenwald (2001) showed that the leverage parameter was lower for small firms during the years of sustained activity, i.e. 1988 and 1989 (their estimation period was 1986-1993). This means that the agency premium was lower for these firms at that time. The neo-classical demand for capital estimated by Beaudu and Heckel (2001) led to greater investment cash flow sensitivity for small firms during years of monetary restriction. In Duhautois (2001), leverage explains small firms' investment from 1985 to 1996 in a regression where sales growth is an omitted variable. Using Euler investment equations, where the cost of debt increases with leverage, Chatelain and Teurlai (2006) showed a cash flow misspecification (which is an indirect test of investment cash flow excess sensitivity consistent with the Lucas critique) for firms with a low dividend/payout ratio or a low investment/retained earnings ratio. Finally, Chatelain and Teurlai (2001) found that small firms with a high variation of debt and a high share of capital financed by leasing displayed an investment leverage excess sensitivity during the economic downturn between 1993 and 1996.

The contribution of this paper is first to allow a greater precision in the estimation of user cost effects by building firm-specific measures of the user cost of capital and allowing for heterogeneity in the UCE across firms. Second, we are able to isolate three groups of firms for which investment is more sensitive to cash flow: firms facing a high risk of bankruptcy, firms belonging to the capital goods sector (which are more sensitive to business cycle fluctuations) and firms making extensive use of trade credit, a potential substitute for short-term bank credit.

The remainder of this chapter is organised as follows. In section 2, we provide an overview of the institutional and macroeconomic background to French corporate investment and financing in the 1990s. Section 3 shows how we obtain a greater precision of the user cost and the financial variable effects on investment, after isolating the heterogeneity in investment demand across different types of firms as precisely as possible. Section 4 compares the effects of a change in monetary policy on investment via the user cost and credit. Section 5 sums up the main conclusions. 


\section{Institutional and macroeconomic background}

Financial deregulation in France occurred in the mid-1980s. This led to considerable changes in the money and financial markets. Treasury bills took on greater importance, new financial instruments appeared on the scene, and new equity markets were set up ("second marché"). There were changes in the regulation of banks' activities. Quantitative credit regulation of banks by the central bank was stopped. All these reforms reduced both the control of the central bank on the quantity of credit supplied by banks and the dependence of non-financial corporations on banks. It is likely that they decreased the effect of the credit channel of monetary policy with respect to what it was before the mid-1980s.

The depressed economic activity of the first half of the 1990s put on hold the development of financial innovations that had benefited small and medium-sized firms (SMEs). The 1993 recession led to a high number of failures, a large amount of bad loans for banks - many of which were triggered by the collapse of the corporate real estate bubble. In addition, the implementation of the capital adequacy ratios further limited banks' willingness and ability to extend corporate loans. Finally, financial innovation that increased the scope of external finance instruments available to the corporate sector resumed after 1996. In particular, it is worth stressing that venture capital finance, promoted by government policies, grew sharply from 1996 to 2000 .

We now briefly review the macroeconomic developments of the 1990s. First, the share of corporate profit in value added, which had increased since 1983, consolidated at at historically high levels over the 1990s. This feature, combined with low demand owing to low-activity years and low investment, had a remarkable effect. The loss of sales affected aggregate profits far less than aggregate investment. Therefore, a high selffinancing ratio prevailed over the period except for the years 1998-2000. For instance, the aggregate retained earnings/investment ratio exceeded $100 \%$ for several years of the decade. A direct consequence of this flow of internal income and, perhaps, of "high" real interest rates for some firms in the early 1990s, was a decrease in leverage, and, in particular, of the share of bank debt in total liabilities. Conversely, this meant an increase of the share of equity. Furthermore, the fall in interest rates from 1995 to 1999 and the decrease of debt led to a decrease in aggregate debt repayments, which in turn further increased aggregate retained earnings. This decrease in the relative size of bank credit to firms may have affected banks' behaviour and their portfolios.

Second, we note relatively high aggregate investment in the first year (1990) and the last years (1998 and 1999) of the sample period our study based on. Between these dates, low investment prevailed: low aggregate investment during the years 1991, 1992, 
1996 and 1997, with slightly higher investment in 1994 and 1995, which followed an exceptionally low investment level during the 1993 recession. Monetary policy shifted from high nominal short-run interest rates from 1990 to 1993 to falling rates from 1994 to 1999. This fall was anticipated on the bonds market, so that there was an inversion of the yield curve from 1991 to 1993 . The high return from short-run debt caused some firms to delay investment and to accumulate cash during this period.

\section{Do some firms experience a tighter liquidity constraint?}

This section complements the results presented in Chatelain et al. $(2003)^{4}$ by investigating the reasons why the introduction of cash flow or cash stock (cash in hand) drives the user cost elasticity down to zero. ${ }^{5}$

First, we define the user cost as a linear function of a microeconomic average interest rate, which includes an agency premium. According to the broad credit channel theory (see Gertler and Hubbard [1988]), this agency premium decreases with respect to collateral, which depends on expected profits, which in turn are very much dependant on expected sales, among other factors (for example, Oliner and Rudebush [1996] state that the agency premium increases with the risk-free interest rate). Owing to the correlation between future profits and past profits, a potential explanation of the decline in the user cost elasticity, when cash flow is added to the regression, may lie in the joint correlation between cash flow, sales and the apparent interest rate (hence user cost). We may face a collinearity problem, which is not solved by the generalised method of moments (GMM).

A second explanation relates to a heterogeneity bias and to the prevalence of selffinancing during the 1990s for some firms observed in the descriptive statistics, at both the macroeconomic and microeconomic level: some firms may depend much more on cash flow than others. In that case, the presence of such firms in the sample may lead to biases in the estimated coefficient and the standard error of the UCE (owing to an omitted dummy variable selecting these firms). This is what we investigate in this chapter.

We found three sample-split criteria such that the long run investment cash flow excess sensitivity differential coefficient across the two groups of firms is significantly different

\footnotetext{
${ }^{4}$ We use an auto-regressive distributed lag (ADL) model written in levels instead of in first differences as in Chatelain et al. (2003). The major difference is that the ADL in levels and its related error correction model have a "higher auto-regressive component" than the ADL in first difference. Consequently, the ADL in levels has a tendency to lead to higher long run estimates for other explanatory variables compared to the ADL in first differences. However, these differences are not always statistically significant in our sample (Chatelain and Tiomo (2002)).

${ }^{5}$ This result is robust to model and instrument selection using the generalised method of moments including optimal upward testing procedures (Andrews (1999), Chatelain (2007)).
} 
from zero. A first set of statistical results on these sample splits is presented in table 1 . Three sample splits, according to the level of trade credit in the firm's liabilities, the level of credit risk of the firm and its sector appeared relevant. Furthermore, in contrast with other countries, sample separation with respect to size, the share of intangibles and the dividend pay out ratio did not yield relevant statistical and economics results.

Estimates allowing for different coefficients across sub-samples defined along these three criteria are shown in table 2. First, we considered different coefficients for firms in the upper quartile with respect to the share of trade credit in total liabilities. Such firms are likely to experience difficulties in securing external finance. Investment cash flow sensitivity is 0.25 for firms with high trade credit-total liabilities ratios, whereas it is zero for other firms, which is consistent with the above interpretation. For all firms, sales growth elasticity is 0.43 , but the user cost elasticity is not significantly different to zero.

Second, we introduced a dummy variable relative to the capital goods sector, which is more sensitive to business cycle fluctuations than other sectors. Long run investment cash flow sensitivity is 0.42 for the capital goods sector, whereas it is only 0.07 for firms in other industrial sectors. Long run sales growth elasticity is 0.29 . It is remarkable that the user cost is now significant for all firms with a long run elasticity of -0.26 .

Third, we separated firms on the basis of their Banque de France "score", which is an evaluation of the credit risk of the firm. Risky firms, whose score function is below -0.3 , present a long run investment cash-flow sensitivity of 0.24 , whereas it is only 0.02 for other firms. This result was expected, as these firms experience more difficulties in getting access to external financing. Sales growth elasticity is now 0.65. Again, as for the regression allowing for a capital goods sector heterogeneity, the user cost elasticity is significant for all firms with a long run value of -0.21 .

Finally, we report the results obtained by using the risky firm dummies when the cash stock replaces the cash flow. For some authors, investment cash flow excess sensitivities are not valid measures of the financing constraint (see Kaplan and Zingales (1997)). Like the cash flow, the stock of cash held by the firm is an indicator of the firm's ability to shield future investment from an expected tightening of borrowing conditions. However, the stock of cash may be less affected by the difficulty in interpreting investment cash flow sensitivity, as liquidity is less likely to be a proxy of expectations of future profits. The use of the stock of cash also alleviates risks of multi-collinearity in the estimation of the investment equation because it is less correlated with sales than cash flow.

When the stock of cash replaces the cash flow in the investment regression and when dummy variables relative to company risk are added to the regression, the user cost elasticity also becomes significant, reaching a nearly unchanged estimate of -0.23 (see 
Table 3). This is an additional robustness check for the user cost elasticity. The previous year's cash stock is a significant determinant of current investment, as a proportion of the previous year's cash may finance this year's investment. However, unlike investment cash flow excess sensitivity, investment cash stock excess sensitivity is not significant for more risky firms. At the same time, risky firms' elasticity of investment with respect to sales is significantly lower than that of other firms. This can either mean that the investment of risky firms reacts much less to sales than that of other firms, or that the test of the financial constraints in the investment equation is mis-specified.

\section{Monetary policy and investment}

The final step in our analysis is to connect investment to monetary policy actions. We do so starting from what we see as our most sensible results, that is the regression with the risk dummy variable. Following Chatelain et al. (2003), we focus on the time pattern and the lags in the reaction of investment to monetary policy shocks. We first consider the effect on investment of a permanent 1 per cent change in the market interest rate through the user cost (Table 4). The elasticity is now different to zero for France, but France still remains the country where the elasticity of investment with respect to the market interest rate is the lowest in the second year (Spain: -0,31; Germany: -0,38; Italy: $-0,41$; see Table 7.11 in Chatelain et al. (2003)).

Table 5 provides the yearly elasticity of contemporaneous investment with respect to cash flow for the group of risky firms (which represents 19 per cent of firms in our sample) and for the other group. In the case of risky firms, the elasticity of investment with respect to cash flow in France follows a similar path to that in Italy and Spain. Low risk French firms, in contrast, are quite similar to German ones (see Table 7.3 in Chatelain et al. (2003)).

We then consider the effect of a permanent change in the market interest rate on cash flow. The higher firms' interest payments, the lower their cash flow, ceteris paribus. Table 6 presents the effect on the growth rate of the capital stock (or investment) of a transitory 1 per cent increase in the interest rate through the cash flow. As in Table 5, the pattern for less risky French firms is close to the German pattern, while that for risky French firms is close to the Italian or Spanish patterns (cf. Table 10 in Chatelain et al. (2003)). These effects are, in general, relatively small in all countries. However, there is also an indirect effect of the market interest rate on sales and hence on cash flow, which is not evaluated here. 


\section{Conclusion}

We reach three major conclusions. First, by allowing heterogeneity across some groups of firms, we isolate more precisely firms which are more sensitive to cash flow than other firms and we improve the precision of the results presented in Chatelain et al. (2003) for France. The user cost elasticity with respect to investment is at the most 0.26 in absolute terms for all the firms of our sample. Unlike the recent papers which assess user cost effects at the firm level in France, this result is obtained using GMM estimates, which are the appropriate estimates for dynamic panel data. Our results thus confirms the direct effect of the interest rate channel on investment, operating through the cost of capital.

Second, we find three groups of firms for which investment is more sensitive to cash flow: firms facing a high risk of bankruptcy, firms belonging to the capital goods sector (which are more sensitive to business cycle fluctuations) and firms making extensive use of trade credit, a potential substitute for short-term bank credit. The rather high investment cash flow sensitivity of these firms (between 0.24 up and 0.42), which represent about $20 \%$ of our sample, confirms the existence of a broad credit channel operating through corporate investment in France. For other firms, investment cash flow sensitivity is close to zero.

Finally, among the four largest euro area countries, the effects of monetary policy on investment, operating through the cost of capital channel, are the lowest in France, while the effects of monetary policy on investment attributed to the credit channel in France were larger than in Germany but lower than in Italy and Spain over the last decade.

\section{References}

Assouline, M. et al. (1998). "Structures et propriétés de cinq modèles macro-économiques français”. Economie et Prévision, 134(3), pp.1-97.

Andrews, D. (1999). "Consistent Moment Selection Procedures for Generalised Method of Moments Estimation". Econometrica, 67(3), pp. 543-64.

Arrelano, M. and Bond, S. (1991). "Some tests of specification for panel data: Monte Carlo evidence and an application to employment equation". The Review of Economic Studies, 58, pp. 277-97.

Beaudu, A. and Heckel, T. (2001). "Le canal du crédit fonctionne-t-il en Europe? Une étude de l'hétérogénéité des comportements d'investissement à partir de données de bilan agrégées”. Economie et Prévision, 147, pp. 117-141. 
Bond, S., Elston, J., Mairesse, J. and Mulkay, B. (1997). “A Comparison of Empirical Investment Equations using Company Panel Data for France, Germany, Belgium and the UK". NBER Working Paper No. 5900.

Chatelain J.B., Generale A., Hernando I., Vermeulen P. and von Kalckreuth U. (2003). "Firm Investment and Monetary Policy in the Euro Area". in "Monetary Policy Transmission in the Euro Area", Angeloni I., Kashyap A. and Mojon B., editors, Cambridge University Press, pp. 133-161.

Chatelain, J.B. (2007). "Improving consistent moment selection procedures for generalized method of moments estimation" Economics Letters, 95(3), pp. 380-385. (mimeo 2003).

Chatelain, J.B. (2002). "Structural modelling of investment and financial constraints: where do we stand?" Research series, National Bank of Belgium, working paper 28. Published as "Structural Modelling of Financial Constraints on Investment: where do we stand?". in “Firms' Investment and Finance Decisions”, (2003), Butzen P. and Fuss C. editors, Edward Elgar, pp.40-58.

Chatelain, J.B. and Teurlai, J.C. (2006). "Euler Investment Equation, Leverage and Cash Flow: an Empirical Analysis on a Panel of French Manufacturing Firms", Journal of Macroeconomics, 28(2), pp. 361-374. (mimeo 2003).

Chatelain, J.B. and Teurlai, J.C. (2001). "Investment and the Cost of External Finance: An Empirical Investigation according to the Size of Firms and their Use of Leasing”, EARIE conference, Dublin.

Chatelain J.B. and Tiomo A. (2002). "Investment and the Cost of Capital in the Nineties in France: A Panel Data Investigation”. IFO Studien, 48(4), pp. 655-684.

Chirinko, R., Fazzari, S. and Meyer, A. (1999). "How Responsive is Business Capital Formation to its User Cost? An Exploration with Micro Data". Journal of Public Economics, 74, pp. 53-80.

Crépon, B. and Gianella, C. (2001). "Fiscalité et coût d'usage du capital: incidence sur l'investissement, l'activité et l'emploi'. Economie et Statistique, 341-342(1/2), pp. 10728.

Crépon, B. and Rosenwald F. (2001). "Des contraintes financières plus lourdes pour les petites entreprises ". Economie et Statistique, 341-342(1/2), pp. 29-46.

Duhautois R. (2001). "Le ralentissement de l'investissement est plutôt le fait des petites entreprises tertiaires”, Economie et Statistique, 341-342(1/2), pp. 47-66. 
Gertler M. and Hubbard R.G. (1988). "Financial Factors in Business Fluctuations". Financial Market Volatility, Federal Reserve Bank of Kansas City, pp 43-64.

Hall, B.H., Mairesse, J. and Mulkay, B. (1999). "Firm-level investment in France and the United States: an exploration of what we have learned in twenty years". Annales d'Economie et de Statistique, 55-56.

Hall, B.H., Mairesse, J. and Mulkay, B. (2000). "Firm-level investment and R\&D in France and the United States: A Comparison". Annales d'Economie et de Statistique, 5556.

Herbet J.B. (2001). "Peut-on expliquer l'investissement à partir de ses déterminants traditionnels au cours de la décennie 90?”. Economie et Statistiques, 341-342, pp.85-106.

Kaplan S.N. and Zingales L. (1997). "Do Investment Cash Flow Sensitivities Provide Useful Measures of Finance Constraints?”. Quarterly Journal of Economics, 112, pp.169215.

Mojon, B., Smets, F. and Vermeulen, P. (2001). "Investment and Monetary Policy in the Euro Area”. European Central Bank Working Paper, 78.

Oliner, S.D. and Rudebush, G.D. (1996). "Is there a Broad Credit Channel for Monetary Policy?”. Federal Reserve Bank of San Francisco Economic Review, n 1, pp. 3-13. 
Table 1: Descriptive Statistics of Various groups of firms (Average values. Number of Observations: 61,237)

\begin{tabular}{|c|c|c|c|c|c|c|c|c|}
\hline & \multirow{2}{*}{$\begin{array}{l}\text { Number } \\
\text { of Firms }\end{array}$} & \multicolumn{6}{|c|}{ Main Variables } \\
\hline & & & $\mathrm{I}(\mathrm{t}) / \mathrm{K}(\mathrm{t}-1)$ & $\Delta \log S(t)$ & $\Delta \log U C(t)$ & $\mathrm{CF}(\mathrm{t}) / \mathrm{K}(\mathrm{t}-1)$ & $\operatorname{LogS}(\mathrm{t})$ & $\log U C(t)$ \\
\hline \multirow{6}{*}{ Sectors } & All sectors & 6946 & 0.122 & 0.0296 & -0.009 & 0.33 & 8.83 & -1.77 \\
\hline & Food products & 929 & 0.12 & 0.01 & -0.014 & 0.27 & 9.3 & -1.8 \\
\hline & $\begin{array}{l}\text { Intermediate } \\
\text { products }\end{array}$ & 3371 & 0.11 & 0.04 & -0.005 & 0.29 & 8.8 & -1.7 \\
\hline & \begin{tabular}{|l|}
$\begin{array}{l}\text { Equipment } \\
\text { goods }\end{array}$ \\
\end{tabular} & 1227 & 0.12 & 0.04 & -0.008 & 0.37 & 8.7 & -1.8 \\
\hline & \begin{tabular}{|l|}
$\begin{array}{l}\text { Consumption } \\
\text { goods }\end{array}$ \\
\end{tabular} & 1286 & 0.15 & 0.01 & -0.02 & 0.47 & 8.7 & -1.8 \\
\hline & Car industry & 133 & 0.12 & 0.03 & -0.02 & 0.31 & 9.8 & -1.8 \\
\hline \multirow{4}{*}{\begin{tabular}{|l|} 
Scoring \\
Function
\end{tabular}} & No score & 481 & 0.12 & 0.003 & 0.004 & 0.30 & 9.0 & -1.8 \\
\hline & Risky Firms & 1293 & 0.12 & 0.03 & -0.008 & 0.30 & 8.6 & -1.8 \\
\hline & Neutral Firms & 1169 & 0.11 & 0.01 & -0.007 & 0.28 & 8.5 & -1.7 \\
\hline & \begin{tabular}{|l|} 
Riskness \\
Firms \\
\end{tabular} & 4003 & 0.13 & 0.04 & -0.01 & 0.36 & 8.9 & -1.8 \\
\hline \multirow{3}{*}{$\begin{array}{l}\text { Trade } \\
\text { Credit }\end{array}$} & $<03$ & 5910 & 013 & 006 & -0003 & 033 & 88 & -18 \\
\hline & & & & & & & & \\
\hline & $>\mathrm{Q} 3$ & 1736 & 0.12 & 0.02 & -0.011 & 0.33 & 8.8 & -1.8 \\
\hline
\end{tabular}

$\mathrm{I} / \mathrm{K}$ : investment over capital; S: sales; $\mathrm{CF} / \mathrm{K}$ : cash flow over capital; UC: user cost 
Table 2: Auto-regressive distributed lags model with $\log (\mathrm{K})$ as endogenous variable.

\begin{tabular}{|c|c|c|c|c|c|c|}
\hline & Coeff. & T-Stats & Coeff. & T-Stats & Coeff. & T-Stats \\
\hline $\log K(t-1)$ & 0.822 & 31.370 & 0.835 & 34.427 & 0.827 & 30.713 \\
\hline $\log K(t-2)$ & -0.050 & -5.670 & -0.052 & -6.206 & -0.066 & -5.339 \\
\hline $\log S(t)$ & 0.075 & 2.788 & 0.041 & 1.743 & 0.091 & 3.210 \\
\hline $\log S(t-1)$ & 0.023 & 0.826 & 0.022 & 0.944 & 0.064 & 2.697 \\
\hline $\log \mathrm{UC}(\mathrm{t})$ & -0.035 & -1.306 & -0.049 & -3.019 & -0.034 & -1.824 \\
\hline Log UC(t-1) & 0.003 & 0.226 & -0.007 & -0.777 & -0.016 & -1.707 \\
\hline $\mathrm{CF}(\mathrm{t}) / \mathrm{K}(\mathrm{t}-1)$ & 0.058 & 2.406 & -0.004 & -0.185 & -0.015 & -0.636 \\
\hline $\mathrm{CF}(\mathrm{t}-1) / \mathrm{K}(\mathrm{t}-2)$ & -0.001 & -0.033 & 0.018 & 2.025 & 0.019 & 2.147 \\
\hline Differential coef. For: & \multicolumn{2}{|c|}{ Low Trade Credit } & \multicolumn{2}{|c|}{ Equipment Goods } & \multicolumn{2}{|c|}{ Risky firms } \\
\hline $\log K(t-1)$ & 0.003 & 0.195 & 0.026 & 0.901 & -0.050 & -0.689 \\
\hline $\log K(t-2)$ & 0.000 & 0.598 & 0.001 & 0.717 & 0.086 & 1.542 \\
\hline $\log S(t)$ & 0.004 & 0.919 & 0.004 & 0.411 & 0.014 & 0.401 \\
\hline $\log \mathrm{S}(\mathrm{t}-1)$ & -0.004 & -0.236 & -0.008 & -0.322 & -0.046 & -1.489 \\
\hline $\log \mathrm{UC}(\mathrm{t})$ & -0.011 & -0.481 & 0.004 & 0.172 & 0.023 & 1.067 \\
\hline Log UC(t-1) & -0.002 & -0.195 & -0.001 & -0.067 & 0.007 & 0.425 \\
\hline $\mathrm{CF}(\mathrm{t}) / \mathrm{K}(\mathrm{t}-1)$ & -0.083 & -3.413 & 0.082 & 3.260 & 0.077 & 2.328 \\
\hline $\mathrm{CF}(\mathrm{t}-1) / \mathrm{K}(\mathrm{t}-2)$ & 0.026 & 1.392 & -0.014 & -0.903 & -0.034 & -2.114 \\
\hline Long term eff. Sales & 0.43* & & $0.29 *$ & & $0.65 *$ & \\
\hline L.T. eff. User Cost & -0.14 & & $-0.26^{*}$ & & $-0.21 *$ & \\
\hline L.T. eff. Cash-Flow & $0.25 *$ & & 0.07* & & 0.02* & \\
\hline Differential coef. For: & \multicolumn{2}{|c|}{ Low Trade Credit } & \multicolumn{2}{|c|}{ Equipment Goods } & \multicolumn{2}{|c|}{ Risky firms } \\
\hline Long term eff. Sales & 0.01 & & 0.02 & & -0.04 & \\
\hline L.T. eff. User Cost & -0.06 & & -0.02 & & 0.11 & \\
\hline L.T. eff. Cash-Flow & $-0.25^{*}$ & & $0.36^{*}$ & & $0.22 *$ & \\
\hline AR2 & -2.266 & $p=0.023$ & -2.077 & $p=0.038$ & -1.993 & $p=0.046$ \\
\hline Sargan & 288.22 & $\mathrm{p}=0.088$ & 275.48 & $\mathrm{p}=0.204$ & 300.91 & $\mathrm{p}=0.031$ \\
\hline
\end{tabular}

Instruments used in the regressions are all explanatory variables lagged 2 to 5. 
Table 3: Auto-regressive distributed lags model with $\log (\mathrm{K})$ as endogenous variable and cash stock as liquidity variable:

\begin{tabular}{|c|c|c|}
\hline & Coeff. & T-Stats \\
\hline & \multicolumn{2}{|c|}{ Less Risky Firms } \\
\hline $\log K(t-1)$ & 0.785 & 36.2 \\
\hline $\log K(\mathrm{t}-2)$ & -0.053 & -4.4 \\
\hline $\log \mathrm{S}(\mathrm{t})$ & 0.094 & 3.79 \\
\hline $\log \mathrm{S}(\mathrm{t}-1)$ & 0.106 & 4.80 \\
\hline $\log \mathrm{UC}(\mathrm{t})$ & -0.053 & -3.01 \\
\hline $\log \mathrm{UC}(\mathrm{t}-1)$ & -0.011 & -1.12 \\
\hline $\operatorname{Cash}(\mathrm{t}) / \mathrm{K}(\mathrm{t}-1)$ & -0.007 & -0.42 \\
\hline $\operatorname{Cash}(\mathrm{t}-1) / \mathrm{K}(\mathrm{t}-2)$ & 0.041 & 2.93 \\
\hline Differential coef. for: & \multicolumn{2}{|c|}{ Risky Firms } \\
\hline $\log K(t-1)$ & -0.033 & -0.54 \\
\hline $\log K(\mathrm{t}-2)$ & 0.055 & 1.10 \\
\hline $\log \mathrm{S}(\mathrm{t})$ & 0.029 & 1.02 \\
\hline $\log \mathrm{S}(\mathrm{t}-1)$ & -0.091 & -3.38 \\
\hline $\log \mathrm{UC}(\mathrm{t})$ & 0.006 & 0.31 \\
\hline $\log \mathrm{UC}(\mathrm{t}-1)$ & 0.011 & 0.67 \\
\hline $\operatorname{Cash}(\mathrm{t}) / \mathrm{K}(\mathrm{t}-1)$ & 0.022 & 1.02 \\
\hline \multirow[t]{2}{*}{$\operatorname{Cash}(\mathrm{t}-1) / \mathrm{K}(\mathrm{t}-2)$} & -0.021 & -1.13 \\
\hline & \multicolumn{2}{|c|}{ Less risky firms } \\
\hline Long term eff. Sales & 0.743* & \\
\hline L.T. eff. User Cost & $-0.238 *$ & \\
\hline L.T. eff. Cash Stock & $0.125^{*}$ & \\
\hline Differential coef. For: & \multicolumn{2}{|c|}{ Risky Firms } \\
\hline Long term eff. Sales & $-0.339 *$ & \\
\hline L.T. eff. User Cost & n.S. & \\
\hline L.T. eff. Cash Stock & n.s. & \\
\hline AR2 & -1.694 & $\mathrm{p}=0.090$ \\
\hline Sargan & 292.01 & $p=0.066$ \\
\hline
\end{tabular}

Instruments used in the regressions are all explanatory variables lagged 2 to 5 . (n.s. : not significant). 
Table 4. Contemporaneous elasticity of investment with respect to the market interest rate through the user cost

\begin{tabular}{|c|c|}
\hline $\mathrm{T}$ & $-0,16$ \\
\hline $\mathrm{T}+1$ & $-0,23$ \\
\hline $\mathrm{T}+2$ & $-0,20$ \\
\hline $\mathrm{T}+3$ & -0.18 \\
\hline
\end{tabular}

Table 5. Contemporaneous elasticity of investment with respect to cash flow

\begin{tabular}{|c|c|}
\hline & Not risky (81\%) - Risky (19\%) \\
\hline $\mathrm{T}$ & $\begin{array}{ll}0.00 & 0.19 \\
\end{array}$ \\
\hline $\mathrm{T}+1$ & 0.06 \\
\hline $\mathrm{T}+2$ & 0.11 \\
\hline $\mathrm{T}+3$ & 0.16 \\
\hline
\end{tabular}

Table 6. Elasticity of investment with respect to the market interest rate through cash flow

\begin{tabular}{|l|cc|}
\hline & \multicolumn{2}{|c|}{ Not risky (81\%) - Risky (19\%) } \\
\hline $\mathrm{T}$ & 0.00 & -0.05 \\
\hline $\mathrm{T}+1$ & -0.02 & -0.09 \\
\hline $\mathrm{T}+2$ & -0.03 & -0.12 \\
\hline $\mathrm{T}+3$ & -0.04 & -0.15 \\
\hline
\end{tabular}

